Al Maal : Journal of Islamic Economics and Banking

http://jurnal.umt.ac.id/index.php/jieb

E-ISSN : $2580-3816$

Vol : No 1 Vol 2 Bulan Januari Tahun 2020

Hlm : $218-234$

DOI : $\quad$ 10.31000/almaal.v1i2.2275

\title{
Kontribusi Para Ilmuwan Muslim Dalam Bidang Ilmu Akuntansi
}

\author{
Warto $^{1 *}$ \\ ${ }^{1}$ Prodi Perbankan Syariah, Universitas Muhammadiyah Tangerang, Indonesia \\ *warto@umt.ac.id
}

\begin{abstract}
The blurring of history in the field of science often occurs. In the 18th century AD Adam Smith wrote an economic theory in the book "An Inquiry Into The Nature and Cause Of The Wealth of Nations" later known that economic theory was adopted from the work of phenomenal cleric Ibn Khaldun, written in his book 'al-Muqaddimah'. The same thing happened in Accounting which has obscured its history by the West. This study aims to explore the historical roots of the contribution of Muslim scientists in the field of Accounting. By using a qualitative descriptive method and historical approach, the results of the study show that Islamic Accounting was developed earlier by Muslims than conventional accounting. Islamic accounting emerged and developed since the time of the Prophet Muhammad around the year 610 AD. Whereas Conventional Accounting was introduced to Lucas Pacioli in 1494 AD. Basics of Sharia Accounting in general have been hinted at in the Koran surah al-Baqarah verse 282 and the sunnahs of the Prophet. The paragraph explains the function and importance of recording transactions, the basics, and their benefits, which are the essence of Accounting. Since the time of the Prophet Muhammad until the time of Khulafaur Rashidin, accounting laws have been applied either on an individual scale, syariah or company, waqf accounting, rights prohibiting the use of assets (hijr) and the state budget. In addition, in that era, the accounting profession was also known as "hafazhatul amwal" (financial supervisor).
\end{abstract}

Keywords: Accounting; Sharia; Muhasaba; Economy.

\begin{abstract}
ABSTRAK
Pengaburan sejarah dalam bidang ilmu pengetahuan acap kali terjadi. Pada abad 18 M Adam Smith menulis sebuah teori ekonomi dalam buku "An Inquiry Into The Nature and Cause Of The Wealth of Nations" belakangan diketahui teori ekonomi tersebut diadopsi dari karya ulama fenomenal Ibn Khaldun yang ditulis dalam bukunya 'al-Muqaddimah'. Hal serupa juga terjadi dalam Ilmu Akuntansi yang telah dikaburkan sejarahnya oleh Barat. Penelitian ini bertujuan untuk menggali akar sejarah mengenai kontribusi ilmuwan muslim dalam bidang Ilmu Akuntansi. Dengan menggunakan metode deskriptif kualitatif dan pendekatan sejarah, hasil penelitian menunjukkan bahwa Akuntansi Syariah jauh lebih awal dikembangkan oleh umat Islam dibandingkan akuntansi konvensional. Akuntansi Syariah muncul dan berkembang sejak zaman Rasulullah SAW sekitar tahun 610 Masehi. Sedangkan Akuntansi Konvensional baru dikenalkan Lucas Pacioli tahun 1494 M. Dasar-dasar Akuntansi Syariah secara umum telah diisyaratkan dalam al-Quran surah al-Baqarah ayat 282 dan sunnah-sunnah Nabi. Dalam ayat tersebut dijelaskan mengenai fungsi dan pentingnya pencatatan transaksi, dasar-dasarnya, dan manfaatmanfaatnya, yang hal tersebut merupakan inti dari Akuntansi. Sejak zaman Rasulullah SAW hingga zaman Khulafaur Rasyidin telah diterapkan undang-undang akuntansi baik skala perorangan, syarikah atau perusahaan, akuntansi wakaf, hak-hak pelarangan penggunaan harta (hijr) dan anggaran negara. Selain itu pada zaman tersebut juga telah dikenal profesi akuntan yang disebut "hafazhatul amwal" (pengawas keuangan).
\end{abstract}

Kata kunci : Akuntansi; Syariah; Muhasabah; Ekonomi. 


\section{Pendahuluan}

Akuntansi merupakan salah satu ilmu yang bersifat aplikatif atau terapan yang pada saat sekarang ini dipakai diseluruh aktifitas kita. Di dalam akuntansi terdapat prinsip, standar, asumsi, teknik, serta prosedur yang dijadikan landasan dalam pelaporan keuangan. Pelaporan tersebut berisi tentang informasi-informasi yang berguna dalam memantau aktifitas ekonomi dan mempengaruhi pengambilan keputusan bagi para pemakainya.

Dalam kehidupan sehari-hari tanpa kita sadari, sesungguhnya kita telah menggunakan jasa akuntansi. Ketika seorang pemilik warung mencatat pembelian barang dagangannya, mencatat siapa saja yang berhutang dari warungnya, memisahkan kotak antara uang yang masuk dari hasil penjualan dengan kotak uang yang dialokasikan untuk belanja kebutuhan barang dagangan dan kebutuhan operasional di warungnya. Maka, ketika itu pada dasarnya pemilik warung tersebut telah menerapkan teknik akuntansi.

Penerapan pengetahuan di bidang akuntansi ini menjadi semakin luas dan kompleks ketika dihadapkan pada bisnis dengan skala yang lebih besar. Seperti ilmu-ilmu lainnya, Ilmu Akuntansi juga berkembang sesuai perkembangan teknologi dan peradaban manusia. Selain itu, faktor kebutuhan juga ikut andil dalam perkembangan akuntansi itu sendiri. Akan tetapi, baik akuntansi maupun ilmu-ilmu lain tidak berkembang dengan sendirinya tanpa adanya hal yang dapat mendorong akuntansi tersebut berkembang dan bertahan hingga sekarang.

Perkembangan Ilmu Akuntansi ini jika dirunut dari sejahanya tidak terlepas dari peranan besar para ilmuwan muslim yang telah memberikan banyak sumbangan pemikiran di dalamnya. Di saat dunia Barat terpuruk dalam masa Dark Age, di sisi lain ternyata abad kegelapan yang dialami oleh dunia Barat justru berbanding terbalik dengan perkembangan keilmuwan pada dunia Islam. Pada masa tersebut adalah masa keemasan umat Islam, dimana banyak para ilmuwan muslim berhasil memberikan karya-karya ilmiah yang signifikan, salah satunya dalam perkembangan Ilmu Akuntansi. Sehingga Ilmu Akuntansi Islam menemukan puncak kegemilangannnya pada tahun $765 \mathrm{H} / 1363 \mathrm{M}$ dengan hadirnya sebuah manuskrip yang disusun oleh Abdullah bin Muhammad bin Kayah al-Mazindarani yang bertajuk Risalah Falakiyah Kitab as-Siyaqat. Namun dalam perjalanan sejarah karya-karya besar ulama Islam dalam bidang Ilmu Akuntansi telah dikaburkan dengan kehadiran sebuah buku berjudul "Summa de Arithmatica Geometria et Propotionalita”.

Munculnya Luka Pacioli di Eropa dengan menawarkan teori Double Entry Accounting merupakan hal baru bagi Barat, sehingga ia dijadikan sebagai referensi utama dalam ilmu akuntansi. Namun hal ini tidak fair, karena jauh sebelum Pacioli telah ada beberapa karya yang mengupas tentang teori tersebut. Banyak referensi mengatakan bahwa dia bukanlah penemu teori Double Entry Accounting System. Berdasarkan uraian tersebut penelitian ini bertujuan untuk menggali akar sejarah mengenai kontribusi para ilmuwan muslim dalam bidang ilmu akuntansi 


\section{KAJIAN LITERATUR Definsi Akuntansi}

Perdebatan mengenai definisi akuntansi telah dimulai sejak tahun 1930 sampai tahun 1970. Para akuntan memiliki pandangan yang berbeda-beda tentang proses akuntansi dalam menguraikan perbedaan teori-teori. Pandangan-pandangan tersebut diantaranya adalah akuntansi sebagai bahasa, akuntansi sebagai catatan peristiwa, akuntansi sebagai realitas ekonomi, akuntansi sebagai sistem informasi, akuntansi sebagai komoditas, dan akhirnya akuntansi sebagai sebuah ideology.

Dalam makalah ini, kami tidak akan membahas perbedaan tersebut, namun akan lebih fokus pada pembahasan mengenai definisi akuntansi dari segi bahasa dan istilah secara konvensional dan syar'iah. Dan kita akan mengkomparasikan dua prespektif tersebut untuk mencari kesatuan makna, kegunaan dan tujuan dari akuntansi itu sendiri.

Secara terminologi akuntansi berasal dari kata accounting yang artinya menghitung atau mempertanggungjawabkan. Akuntansi digunakan di hampir seluruh kegiatan bisnis di seluruh dunia untuk mengambil keputusan sehingga disebut sebagai bahasa bisnis.

Dalam bahasa Arab akuntansi berarti al-Muhasabah, dari akar kata hasaba, yuhasabu, hisab, muhasabah, yang artinya penghitungan, akunting atau pertanggungjawaban. Akar kata ini dalam al-Quran banyak sekali digunakan dan cukup populer dikalangan umat Islam.

Begitu populernya kata "al-Muhasabah" dalam al-Quran, sehingga kita bisa menjumpainya dalam banyak ayat. Sebagai muslim, al-Quran dan Hadits adalah kitab undang-undang yang kita jadikan sebagai referensi bagi setiap persoalan dan aktifitas dalam kehidupan kita.

Lalu, apakah ada Akutansi dalam al-Quran? Kalau kita hendak mencari kata "akuntansi" dalam bahasa populer sebagaimana yang digunakan dalam dunia bisnis saat ini, secara apa adanya, maka itu tidak ada dalam al-Quran. Namun makna dasar, pemahaman, substansi dan tujuannya, al-Quran sudah mendahului para pakar akuntansi jauh 1400 tahun yang lalu. Sebelum orang mengenal istilah Matematika dan Akuntansi.

Akar kata hasaba, yuhasabu, hisab, hasib banyak sekali disebutkan dalam alQuran, seperti di dalam surat (QS. 2:284), (QS. 6:62), (QS. 21:47), (QS. 65:8) dan (QS. 84:8). Mari kita amati firman Allah SWT berikut;

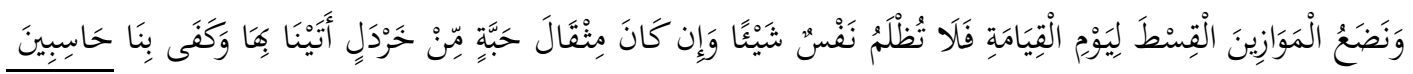

"Kami akan memasang timbangan yang tepat pada hari kiamat, maka tidaklah dirugikan seseorang barang sedikitpun. Dan jika (amalan itu) hanya seberat biji sawipun pasti kami mendatangkan (pahala)nya. Dan cukuplah Kami sebagai Pembuat perhitungan”. (QS. 21:47)

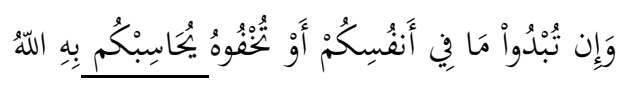

"Dan jika kamu melahirkan apa yang ada di dalam hatimu atau kamu menyembunyikannya, niscaya Allah akan membuat perhitungan dengan kamu tentang perbuatanmu itu". 
Ayat-ayat di atas, menegaskan bahwa Allah akan memintai pertanggungjawaban manusia atas apa yang ia kerjakan di atas dunia ini. Semua usaha, aktifitas yang dilakukan manusia akan dihitung semuanya oleh Allah SWT. Bukankah dengan demikian, ayat-ayat tersebut memotivasi kita untuk membiasakan diri dengan menghitung laba-rugi yang akan kita peroleh dalam kehidupan ini.

Dalam al-Quran kata hisab selalu dikaitkan dengan untung/laba-rugi. Dan ini adalah hakekat dari fungsi akuntansi yang memperhitungkan laba-rugi dalam aktifitas berbisnis. Baik bisnis di dunia dengan manusia atau bisnis ahirat dengan Allah. Hal ini karena laba dalam dalam bahasa Arabnya arribhu, sinonim dari kata az-ziyadah yang artinya bertambah. Jika dibuat simbol akan menjadi (+). Dalam bahasa al-Quran nilai (+) adalah pahala, yang bernilai baik. Dalam terminologi kontemporer disebut point atau debit. Sedangkan rugi dalam terminologi Arabnya adalah al-Khusr yang dilambangkan (). Kerugian dalam bahasa al-Quran adalah dosa atau kredit. Setiap dosa akan mengurangi kebaikan. Dan manusia dalam kehidupan dunia ini sedang mempersiapkan laporan labarugi tersebut. Demikian halnya Ilmu Akuntansi dibuat dalam rangka untuk membuat laporan keuangan atau data keuangan terkait laba-rugi dan debit-kredit.

Manusia dalam kehidupan dunia ini adalah bekerja untuk mencari keuntungan atau falah dalam kehidupan dunia dan ahiratnya. Dan setiap perbuatannya dicatat dan dihitung dalam buku debit dan kredit oleh malaikat Raqib dan Atid. Bahkan dalam hal ini pembukuannya dilakukan secara terpisah, antara debit dan kredit.

Ayat-ayat ini memotivasi kita untuk menjadi para akuntan yang selalu mengevaluasi diri, sudah berapa banyak keuntungan yang kita raih dan seberapa banyak kerugian yang kita alami. Sebelum kerugian itu benar-benar diraih dalam kehidupan yang kedua kelak, yaitu kehidupan akhirat.

Dalam prespektif Hadits, Rasulullah juga menegaskan;

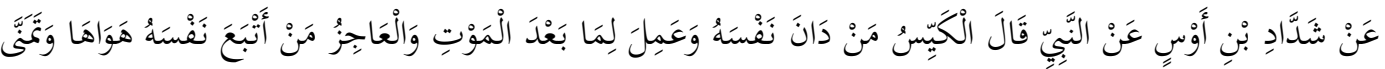

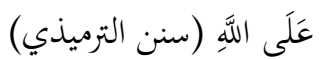

"Orang yang paling pandai ialah orang yang melakukan perhitungan terhadap dirinya sendiri dan beramal untuk bekal sesudah mati."

Demikian juga para sahabat, Umar berkata;

$$
\text { قال عمر رضي الله عنه: "حاسبوا أنفسكم قبل أن تحاسبوا، وزنوا أنفسكم قبل أن توزنوا" }
$$

Umar r.a. berkata, "Hisablah diri kalian sendiri sebelum dihisab, dan timbanglah amal perbuatan kalian sebelum ditimbang"

Makna Akuntansi dalam pandangan al-Quran dan hadits bersifat umum dan menyeluruh yang meliputi seluruh aktifitas manusia dalam kehidupan berinteraksi dan bertransaksi, dalam hubungannya dengan ibadah maupun transaksi sosial ekonomi. Hal demikian, karena Al-Quran dan hadits menjadi standar regulasi bagi segenap transaksi manusia. Karena akuntansi itu bagian dari ilmu sosial maka sebenarnya cakupannya sangat luas dan meliputi seluruh aspek kehidupan manusia. 
Di dalam dunia bisnis kontemporer saat ini Ilmu Akuntansi dibatasi dan secara spesifik digunakan untuk mengolah data keuangan dalam berbagai bidang usaha baik yang melayani jasa, barang dan industri.

Akuntansi secara umum merupakan laporan dari kegiatan jasa dan usaha. Fungsinya adalah menyajikan informasi kuantitatif terutama yang bersifat keuangan dari suatu entitas ekonomi (perusahaan) yang ditujukan untuk pengambilan keputusan ekonomi dalam memilih berbagai pilihan tindakan. Atau Akuntansi adalah suatu proses mencatat, mengklasifikasi, meringkas, mengolah dan menyajikan data, transaksi serta kejadian yang berhubungan dengan keuangan sehingga dapat digunakan oleh orang yang menggunakannya dengan mudah dimengerti untuk pengambilan suatu keputusan serta tujuan lainnya.

Dalam pengertian lain menurut Warren menjelaskan bahwa secara umum, akuntansi dapat didefinisikan sebagai sistem informasi yang menghasilkan laporan kepada pihak-pihak yang berkepentingan mengenai aktivitas ekonomi dan kondisi perusahaan. Sementara itu, Littleton menjelaskan bahwa ujuan utama dari akuntansi adalah untuk melaksanakan perhitungan periodik antara biaya (usaha) dan hasil (prestasi). Konsep ini merupakan inti dari teori akuntansi dan merupakan ukuran yang dijadikan sebagai rujukan dalam mempelajari akuntansi. Dengan demikian, secara umum akuntansi dapat didefinisikan sebagai suatu sistem yang mengidentifikasi, mencatat dan memproses informasi mengenai aktivitas bisnis suatu entitas menjadi laporan keuangan, dan mengkomunikasikan hasil usaha perusahaan kepada para pengambil keputusan.

Jadi akuntansi bukan hanya kegiatan pencatatan transaksi bisnis perusahaan saja. Pengertian akuntansi lebih luas dari sekedar pencatatan. Akuntansi juga meliputi kegiatan menganalisa dan menginterpertasi aktivitas ekonomi suatu perusahaan untuk kemudian dikomunikasikan kepada pengguna laporan akuntansi sehingga informasi tersebut dapat digunakan untuk pengambilan keputusan secara tepat.

Secara singkat, tujuan utama akuntansi adalah menyajikan informasi ekonomi dari suatu kesatuan ekonomi kepada pihak-pihak yang berkepentingan. Informasi ekonomi tersebut disajikan dalam banyak ragam laporan akuntansi (accounting reports) yang dihasilkan oleh suatu sistem akuntansi. Salah satu jenis laporan yang utama adalah laporan keuangan (financial statement). Secara umum proses akuntansi dapat dilihat dari ilustrasi berikut:

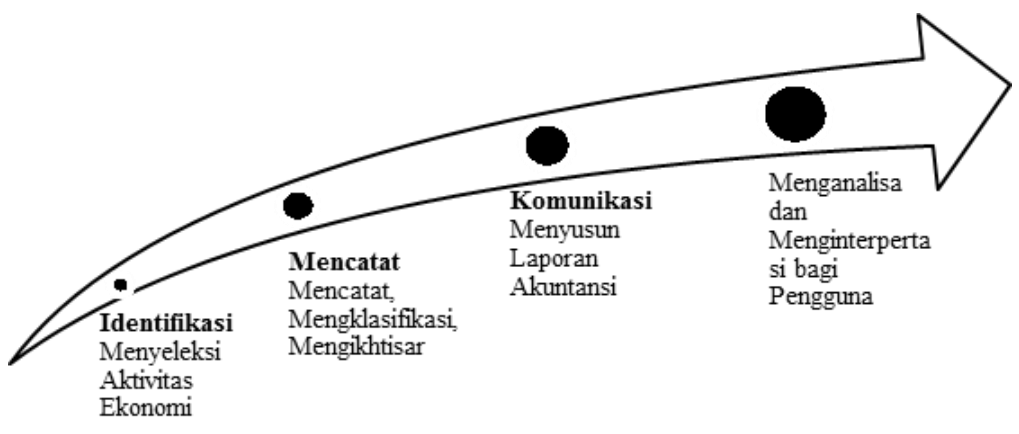




\section{Akuntansi Sebagai Ilmu Sosial}

Akuntansi merupakan bagian dari ilmu sosial. Dengan pengertian bahwa akuntansi bersifat manusiawi atau humanis. Ia sesuai dengan fitrah manusia dan dapat dipraktikkan oleh manusia yang selalu berinteraksi dan melakukan transaksi dengan orang lain secara dinamis dalam kehidupan sehari-hari (Triyuwono, 2017)

Dari prinsip humanis ini dapat menurunkan konsep sosio economic. Konsep dasar sosio economic mengindikasikan bahwa teori akuntansi tidak terbatas pada transaksitransaksi ekonomi saja, tetapi juga mencakup keseluruhan transaksi sosial, yang mencakup aspek sosial, mental dan spiritual. Akuntansi dipergunakan dihampir seluruh aktifitas atau kegiatan ekonomi, pelayanan jasa, pemerintahan, organisasi dan seluruh aktifitas sosial lainnya (Ahmad Faraghli. t.k).

Sebagai bagian dari ilmu sosial, akuntansi merupakan bentuk ilmu pengetahuan yang diderivasi dari nilai-nilai normatif al-Quran dan Hadits dalam bentuk yang lebih konkret dan operasional. Dengan demikian ajaran-ajaran normatif Islam dapat dipraktikkan dan dibumikan dalam aktifitas transaksi sehari-hari. (Triyuwono, 2017). Atau dengan kata lain, nilai-nilai Islam yang meliputi iman, ilmu dan amal dapat diterapkan dalam Akuntasi Syariah, oleh para pelaku ekonomi syariah dalam melakukan pembukuan dan pembuatan laporan keuangan pada setiap transaksi yang dilakukan.

Sebagai ilmu sosial, akuntansi syariah memiliki dua aspek penting, yaitu aspek substansi dan bentuk, atau aspek ruhiyah dan jasadiah, atau nilai dan penampilan. Aspek substansi ini bersifat konstan atau tidak boleh berubah, yaitu berupa nilai-nilai ketauhidan dalam akuntansi. Nilai ketauhidan yang mengandung unsur-unsur keimanan, kejujuran dan keadilan. Substansi dalam konteks ini tidak boleh berubah dan berlaku umum sepanjang masa dengan tidak dibatasi oleh ruang, waktu, dan keadaan.

Ini berbeda dengan bentuk akuntansi yang bersifat dinamis dan boleh berubah menyesuaikan keadaan, waktu dan ruang, social, kemajuan teknologi dan ilmu pengetahuan. Bentuk akuntansi di sini diantaranya meliputi perubahan teknik dan prosedur, perlakuan, bentuk laporan keuangan dan lainnya. Dengan demikian bentuk praktik akuntansi di Negara Arab akan berbeda dengan bentuk praktik akuntansi di Indonesia. Bentuk praktik akuntansi pada tahun 1800an akan berbeda dengan bentuk praktik akuntansi pada tahun 2011 sekarang ini. Itulah sebabnya sangat wajar bila bentuk akuntansi di masing-masing Negara berbeda, beda generasi berbeda modelnya.

Perkembangan akuntansi sebagai salah satu cabang ilmu sosial telah mengalami pergeseran yang sangat mendasar dan berarti, terutama mengenai kerangka teori yang mendasarinya dikonsep dan disetir mengikuti perubahan yang terjadi dalam kehidupan masyarakat.

Demikian halnya dengan kontruksi akuntansi konvensional menjadi Akuntansi Islam (syariah) yang lahir dari nilai-nilai budaya masyarakat dan ajaran syariah Islam yang dipraktikan dalam kehidupan sosial-ekonomi. Akuntansi Syariah dapat dipandang sebagai kontruksi sosial masyarakat Islam guna menerapkan ekonomi Islam dalam kegiatan ekonomi. Akuntansi syariah merupakan sub-sistem dari sistem ekonomi dan keuangan Islam, digunakan sebagai instrument pendukung penerapan nilai-nilai Islami dalam ranah akuntansi, fungsi utamanya adalah sebagai alat manajemen menyediakan informasi kepada pihak internal dan eksternal organisasi (Safira, 2013). 
Akuntansi tumbuh dan berkembang dalam suatu lingkungan organisasi sosial yang bersifat terbuka. Disiplin ini berada dalam lingkaran interaksi kehidupan antara manusia atau kelompok manusia dalam kehidupan sehari-sehari. Maka akuntansi selalu berkembang sejalan dengan budaya manusia.

Interaksi di antara manusia atau kelompok manusia tercipta karena;

- Mekanisme tukar menukar kepentingan

- Kebutuhan adanya aturan main

- Sikap dan perilaku individu ataupun kelompok

- Sistem nilai sekelompok masyarakat

- Anomali perikehidupan sosial

Dengan melihat realitas di atas ilmu akuntansi memang berada dalam lingkungan ilmu sosial, namun ahir-ahir ini mulai muncul diskusi yang mempersoalkan dimanakah letak dan kedudukan akuntansi dalam struktur ilmu pengetahuan. Banyak para pakar akuntansi yang bergeser dalam memberikan definisi akuntansi dari sebagai bagian dari seni sampai menjadi bagian dari ilmu teknologi, khususnya rekayasa system informasi. Meskipun pergeseran pemahaman ini belum sepenuhnya diterima, namun dikalangan pemikir muda, pemikiran baru tersebut dapat diterima. Hal ini disebabkan oleh pertumbuhan ilmu lain yang sangat menunjang pengembangan ilmu akuntansi, yaitu ilmu computer.

\section{Metode Penelitian}

Penelitian ini menggunakan metode deskriptif kualitatif dengan pendekatan historis. Yang dimaksud pendekatan historis dalam penelitian ini adalah sebuah pendekataan yang berupaya untuk mensistematiskan fakta dan data masa lalu melalui pembuktian, penafsiran dan generelisasi. Selain itu, penelitian ini juga termasuk jenis penelitian pustaka (library research). Data yang digunakan berasal dari berbagai referensi berupa buku, jurnal ilmiah, internet, catatan dan tulisan yang berkaitan dengan Ilmu Akuntansi secara spesifik sebagai acuan dan bahan analisis.

\section{HASIL DAN PEMBAHASAN Jejak Akar Sejarah Akuntansi}

Akuntansi konvensional telah dikenal sejak manusia mengenal angka, yaitu sejak zaman Firaun di Mesir antara tahun 3000-1000 SM. Juga pada sejak zaman raja Hammurabi di Babilonia 2500-500 SM. Yang kemudian dikenal dengan perjanjian Hammurabi. Pada waktu itu masyarakat Mesir dan Babilonia telah mengenal adanya ilmu manajemen. Sebagaimana saat itu Firaun telah menerapkan ilmu manajemen dalam pembangunan Piramida (Harahap, 2004). 
AKUNTANSI FINANCIAL

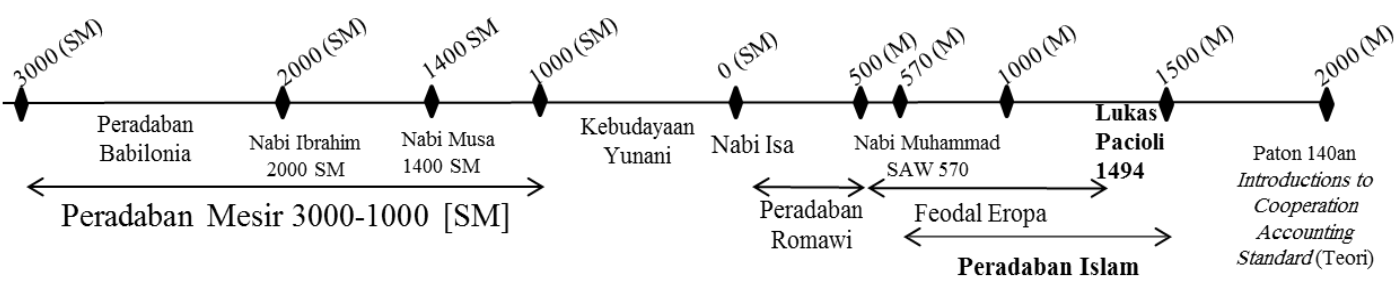

AKUNTANSI MANAJEMEN

- ASDM

- BEHAVIORA ACC

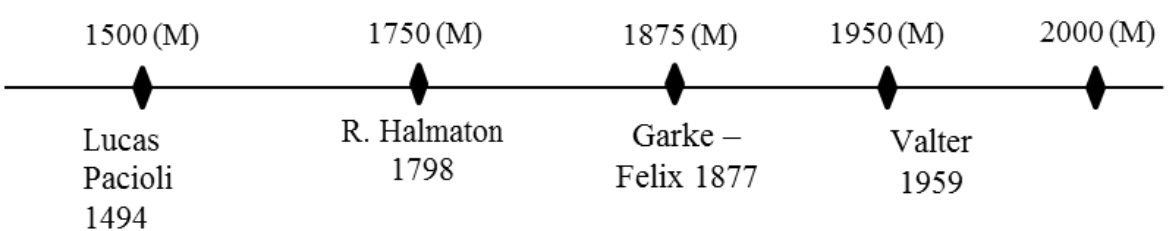

Sumber: Fakultas Ekonomi Universitas Mercu Buana Jakarta

Penelusuri jejak-jejak sejarah akuntansi dalam Islam telah membawa pada akar sejarahnya yang dimulai dari zaman Rasulullah sebagai pembawa risalah Islam. Pada masa awal Islam, akuntansi telah dikenal sejak zaman Rasulullah, yang secara umum termuat dalam beberapa surat (QS. 2:284), (QS. 6:62), (QS. 21:47), (QS. 65:8) dan (QS. 84:8), dan secara khusus termuat dalam surat al-Baqarah Ayat 282.

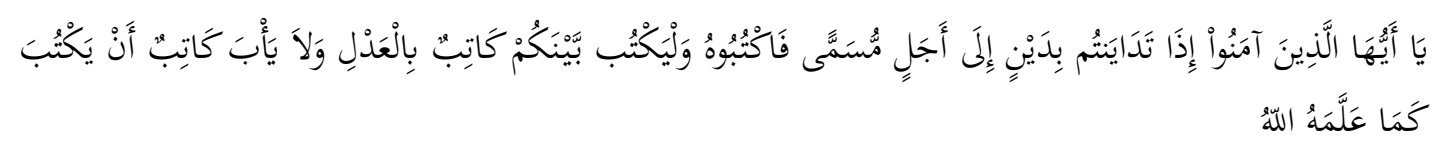

"Hai orang-orang yang beriman, apabila kamu bermu'amalah tidak secara tunai untuk waktu yang ditentukan, hendaklah kamu menuliskannya. Dan hendaklah seorang penulis di antara kamu menuliskannya dengan benar. Dan janganlah penulis enggan menuliskannya sebagaimana Allah telah mengajarkannya, maka hendaklah ia menulis, dan hendaklah orang yang berhutang itu mengimlakkan (apa yang akan ditulis itu), dan hendaklah ia bertaqwa kepada Allah Tuhannya, dan janganlah ia mengurangi sedikitpun daripada hutangnya"

Ayat di atas mengungkapkan indikasi akuntansi yang meliputi; hutang dan piutang, jatuh tempo hutang, penulis hutang, keharusan berbuat keadilan dalam penulisan, menuliskan perjanjian secara jelas, dua orang saksi, dan tujuan pencatatan (Samer Kantakji, 2004).

Sebagai kitab suci umat Islam, al-Quran menganggap akuntansi sebagai suatu masalah yang penting. Dalam banyak ayat di atas banyak disinggung tentang al-Hisab, dan secara khusus diturunkan ayat terpanjang, yakni surah al-Baqarah ayat 282 yang menjelaskan fungsi-fungsi pencatatan transaksi, dasar-dasarnya, dan manfaatmanfaatnya 
Dengan demikian, dapat kita saksikan dari sejarah, bahwa Islam lebih dahulu mengenal system akuntansi, karena al-Quran telah diturunkan pada tahun $610 \mathrm{M}$, yakni 800 tahun lebih dahulu dari Lucas Pacioli yang menerbitkan bukunya pada tahun 1494 .

Dalam sejarah Rasulullah SAW sendiri pada masa hidupnya juga telah mendidik secara khusus beberapa sahabat untuk menangani profesi akuntan dengan sebutan "hafazhatul amwal' (pengawas keuangan). Juga telah memerintahkan 42 orang sahabat yang berkompeten di bidangnya masing-masing dan di gaji untuk mengurusi Rumah Zakat (Baitul Maal).

Dengan demikian jelas pula begitu besarnya perhatian Islam terhadap akuntansi di dalam perekonomian Islam bahkan telah diterapkan pula beberapa undang-undang akuntansi yang telah ada, seperti undang-undang akuntansi untuk perorangan, perserikatan (syarikah) atau perusahaan, akuntansi wakaf, hak-hak pelarangan pengunaan harta (hijir), dan angaran negara. Maka semenjak tahun pertama hijriah sampai 23 hijriah, Rasulullah SAW telah membangun pondasi akuntansi Islam yang detail yang di belakang hari akan diteruskan oleh sahabat-sahabat beliau, sebagai khalifah penerus jejak langkahnya.

Sepeninggal Rasululullah SAW pada tahun 632 M diangkatlah Abu Bakar AshShiddiq sebagai khalifah pertama umat Islam. Abu Bakar memerintah selama dua tahun yaitu semenjak tahun 632-634 M. Selama sekitar 27 bulan memimpin Abu Bakar telah banyak menangani segenap kasus dan persoalan, diantaranya kasus orang-orang yang menolak untuk membayar zakat kepada negara. Pada masa Rasulullah, pendapatan baitul maal (selain hewan) disimpan di Masjid Nabawi, tapi pada saat itu tidak ada uang tunai yang tersisa. Berapa pun uang yang masuk, langsung diditribusikan pada saat itu juga termasuk ketika Baitul Maal menerima uang sebesar 80.000 dirham dari Bahrain.

Abu Bakar meninggal dunia, digantikan oleh khalifah Umar Bin Khattab. Beliau memerintah kaum muslimin selama 10 tahun (13-23 H/ 634-644 M). Selama masa pemerintahan Umar banyak sekali perkembangan ekonomi yang dijumpai dan dirasakan umat Islam. Umar banyak membuat kebijakan-kebijakan di bidang ekonomi. Karena perluasaan daerah terjadi dengan cepat, maka Khalifah segera mengatur adiministrasi negara dengan mengacu pada administrasi yang sudah berkembang terutama di Persia, yaitu dengan membagi pemerintahan menjadi 8 wilayah propinsi: Mekkah, Madinah, Syria, Jazirah, Basrah, Kufah, Palestina dan Mesir.

Di masa beliau banyak departemen didirikan untuk memaksimalkan roda dan fungsi pemerintahan. Beliau juga telah menertibkan sistem pembayaran gaji dan pajak tanah. Pengadilan didirikan untuk memisahkan antara legislative dan yudikatif. Dibentuk pula jawatan kepolisian, jawatan pekerjaan umum, mendirikan Bait al-Mal, menempa mata uang dan menciptakan tahun hijriah.

Di masa Umar Bin Khattab, perkembangan bidang ekonomi ini sangat pesat dan menjadi isu penting, hal ini dibuktikan dalam pernyataan pidato pengangkatannya sebagai khalifah. Didalam pidatonya "Platform" kebijakan ekonomi yang akan diterapkannya meliputi hal-hal seperti berikut;

Negara Islam mengambil kekayaan umum dengan benar, dan tidak mengambil hasil dari Kharaj dan harta Fai' yang diberikan Allah kepada rakyat kecuali melalui mekanisme yang benar. 
Negara memberikan hak atas kekayaan umum, dan tidak ada pengeluaran kecuali sesuai dengan haknya; dan negara menambahkan subsidi serta menutup hutang.

Negara tidak menerima harta kekayaan dari hasil yang kotor, seorang penguasa tidak mengambil harta umum kecuali seperti pemungutan harta anak yatim. Jika dia berkecukupan, dia tidak mendapat bagian apapun. Kalau dia membutuhkan, maka dia memakai dengan jalan yang benar.

Bahkan di zaman Umar Bin Khattab, telah membuat Anggaran Pendapatan Negara, yang di zaman ini dikenal dengan APBN. Umar Bin Khattab membaginya menjadi 4 bagian., yaitu:

Bagian I : Khusus untuk pengeluaran harta zakat, yaitu untuk kaum fakir, miskin, orang yang menangani zakat, orang yang terpikat oleh Islam, budak, orang yang terjerat hutang, sbilillah dan Ibnu sabil. SWT.

Bagian II : Khusus untuk pengeluaran dari 1/5 harta rampasan, yaitu untuk Allah

Bagian III : Khusus untuk pengeluaran harta yang diserahkan kepada baitul mal berupa barang temuan dan peningalan yang tidak ada ahli warisnya, maka sumber pemasukan ini digunakan untuk memberikan infaq kepada kaum fakir.

Bagian IV: Khusus untuk pembiayaan kemaslahatan umum. Ini dibiayai dari sumber pemasukan Jizyah, Kharaj dan 'Usyur.

Demikian majunya perekonomian di zaman Umar Bin Khattab dan ini merupakan prototipe dari perekonomian Islam sesungguhnya, maka mungkinkah perkembangan ekonomi dan manajemen pemerintahan sekompleks itu belum mempunyai pencataatan atau pedoman akuntansi? Maka bisa dipastikan bahwa di zaman Umar Bin Khattab ini telah ada Akuntansi Islam, tetapi seperti apa formatnya, misalnya apakah telah ada buku besar, jurnal, laporan rugi laba dan seterusnya penulis belum menemukan literatur yang lebih rinci.

Apa yang telah dirintis oleh Umar dilanjutkan oleh Ustman Bin Affan dan Ali bin Abi Thalib ra. Khalifah Ali dalam melaksanakan tugasnya mempunyai konsep yang matang di dalam pemerintahan. Beliau mengangkat bendahara Negara dan setiap hari Kamis mampu mendistribusikan seluruh pendapatan yang ada di Baitul Maal di Madinah, Busra dan Kufah dengan semua perhitungan yang diselesaikan pada hari itu juga dan perhitungan baru dimulai Sabtu berikutnya.

Pada masa Khulafaur Rasyidin telah terdapat undang-undang Akuntansi yang diterapkan untuk perorangan, perserikatan (syarikah) atau perusahaan, akuntansi wakaf, hak-hak pelarangan penggunaan harta (hijr) dan anggaran negara.

Di era khalifah setelah para sahabat, reliabilitas laporan keuangan pemerintahan dikembangkan oleh Umar Bin Abdul Aziz (681-720M) dengan kewajiban mengeluarkan bukti pemerimaan uang.

Al-Waleed bin Abdul Malik ( $705 \pm 715 \mathrm{M})$ mengenalkan catatan dan register yang terjilid. Evolusi perkembangan pengelolaan buku akuntansi mencapai tingkat tertinggi pada masa Daulah Abbasiah. Pada masa itu, akuntansi telah diklasifikasikan pada beberapa spesialisasi seperti akuntansi peternakan, akuntansi pertanian, akuntansi bendahara, akuntansi konstruksi, akuntansi mata uang, dan pemeriksaan buku/auditing. 
Sistem pembukuan menggunakan model buku besar, meliputi;

- Jaridah al-Kharaj (menyerupai receivable subsidiary ledger), menunjukkan hutang individu atas zakat tanah, hasil pertanian, serta hutang hewan ternak dan cicilan hutang individu dicatat di satu kolom dan cicilan pembayaran di kolom lain

- Jaridah an-Nafakat (jurnal pengeluaran)

- Jaridah al-Maal (jurnal dana), mencatat penerimaan dan pengeluaran dan zakat

- Jaridah al-Musadareen, mencatat penerimaan denda/sita dari individu yang tidak sesuai syariah, termasuk korupsi

Akuntansi terus berkembang sejak ditemukannya angka oleh pakar matematika muslim, al-Khawarizmi (Algoarism), pada awal abad 9 M (780-850), penemu angka nol, dan penulis buku: al-Mukhtashar fi Hisab al-Jabr wa al-Muqabala (Liber al-Gebras et Almucabola), yang mendapat julukan "Bapak Matematika".

Berikutnya muncul pada abad ke-15, di Italia akuntansi dipopulerkan oleh Luca Pacioli, seorang Pendeta, yang menulis buku "Summa de Arithmatica Geometria et Propotionalita" dengan memuat satu bab mengenai "Double Entry Accounting System". Munculnya Luka Pacioli di Eropa dengan menawarkan teori Double Entry Accounting merupakan hal baru bagi mereka, sehingga mereka menjadikannya sebagai referensi utama dalam akuntansi. Namun hal ini tidak fair, karena jauh sebelum Pacioli telah ada buku yang mengupas tentang teori tersebut. (Ahmad Abdulkadir Ibrahim: 2015) Banyak referensi mengatakan bahwa dia bukanlah penemu teori Double Entry Accounting System. Semua itu akan kita kupas pada sub berikut.

\section{Kontribusi Para Ilmuwan Muslim Dalam Ilmu Akuntansi}

Klaim kemunculan ilmu akuntansi dari Italia oleh Luka Pacioli tidak diterima oleh cendekiawan muslim. Karena sumber yang lebih valid menyatakan bahwa seorang tokoh muslim bernama Abdullah bin Muhammad bin Kayah al-Mazindarani telah mendahului Luca Pacioli dalam bidang Akuntansi. Melalui bukunya Risalah al-Falakiyah kitab asSiqayat, pada tahun 1363 Masehi Abdullah al-Mazindarani telah membuat rumusan mengenai akuntansi. Buku tersebut dalam bentuk manuskrip yang disimpan di perpustakaan Sultan Sulaiman al-Qanuni di Istambul Turki, dan tercatat di bagian manuskrip dengan nomor 2756. Di dalam manuskrip tersebut al-Mazindarani telah menguraikan tentang akuntansi dan sistem akuntansi di negara Islam. Huruf yang digunakan dalam tulisan ini berupa huruf Arab, tetapi bahasa yang digunakan terkadang bahasa Arab, terkadang bahasa Parsi dan terkadang pula bahasa Turki yang populer di Daulat Utsmaniyah. Jadi sudah sepantasnya jika tehnik tata buku berpasangan yang diklaim sebagai penemuannya digugat kebenarannya oleh para ilmuwan, karena Fra Luca Bartolomeo de Pacioli bukan pencipta atau perumus sistem tersebut. Ia hanya mendeskripsikan secara sederhana metode yang digunakan oleh para pedagang di Venesia selama jaman Renaisance Italia. (Triyuwono, 2017). Bahkan Littlelon dan Yame (1978) menduga kalau system tata buku berpasangan ini berasal dari Spanyol dengan dengan alasan bahwa kebudayaan dan teknologi Spanyol pada abad pertengahan tersebut jauh lebih maju dan unggul dibandingkan dengan peradaban Eropa, dan pada saat itu Spanyol adalah Negara muslim yang menjadi pusat kebudayaan dan teknologi Eropa. Hal 
lain yang memperkuat adalah bahwa saat itu, tahun $1494 \mathrm{M}$ atau tahun $893 \mathrm{H}$ Eropa masih hidup pada masa kegelapan, kaum muslimin telah menggunakan akuntansi dan ikut andil dalam mengembangkannya. Saat itu, peradaban Islam dalam sebuah fase yang subur dan berkembang pesat di dunia dengan syariat Islam sebagai pondasinya dan berhasil mengintegrasikan antara tuntunan spiritual dan material

Tokoh-tokoh muslim seperti, al-Khawarizmi 780-850, Abu Kamil Suja' 850-956 M, al-Khazin 961 M, al-Kharki, Ibnu al-Banna 1256 M, Abu Mansur al-Baghdadi, alKalasadi, al-Karaji, al-Kashi dan al-Kuyandi, telah memberikan kontribusi yang besar dan signifikan dalam Akuntansi (Barmawi, 2006). Penemuan angka-angka yang dikenal sampai saat ini sebagai angka Arab-Hindi atau al-Binji dan angka nol oleh al-Khwarizmi sangat berperan besar bagi perkembangan ilmu Akuntansi sampai saat ini.

Akuntansi sebagai bagian yang inheren dengan kultur, identitas, dan kebudayaan serta peradaban Islam telah dimulai sejak pertama kali Baginda Rasulullah SAW mendirikan sebuah masyarakat dan negara Islam di Madinah. Terutama ketika bertambahnya pemasukan negara dari pelbagai hasil taklukan dan zakat yang dikumpulkan dalam lembaga pengumpulan pemasukan harta negara yang kelak dikenal dengan Baitul Maal. (Safira, 2013).

Artinya proses penumbuhan akuntansi di dunia Islam telah digunakan sekitar 745 tahun sebelum kemunculan buku Pacioli yang berjudul Summa De Arithmetica, Geometry, proportion. Kemudian barulah Akuntansi Islam menemukan puncak kegemilangannnya di tahun $765 \mathrm{H} / 1363 \mathrm{M}$ dengan sebuah manuskrip yang disusun oleh Abdullah bin Muhammad bin Kayah al-Mazindarani. bertajuk Risalah Falakiyah Kitab as-Siyaqat. Walaupun sebelum al-Mazindarani menyusun manuskripnya tersebut. Penulis muslim lainnya yang juga telah menyusun sebuah karya tentang perkembangan Akuntansi dan penggunaaanya dalam masyarakat Islam juga telah dimulai oleh anNuwairi (734H/1336M) dan Ibnu Khaldun (167H/784M)

Disinilah perlunya pemurnian informasi secara fair dan jujur, yaitu pada saat mata dunia tertutup oleh segenap keangkuhan pada karya gemilang yang pernah direntas oleh putra-putri Islam terbaik sepanjang masa. Pada saat jejak-jejak ingatan kolektif masyarakat terkaburkan oleh sikap kesengajaan untuk menghilangkan kegemilangan yang pernah direntas oleh tangan-tangan insan berdedikasi dan berkeimanan.

Sebagaimana pemaparan pada paragraph sebelumnya, jauh sebelum pendeta Kristen pada tahun 1494 M yang bernama Luca Pacioli dalam jangka perbedaan waktu 131 tahun, tahun 1363 M Abdullah bin Muhammad al-Mazindarani telah merentas pembukuan dua belas kolom atau kolom tunggal, dan disempurnakan olehnya untuk selanjutnya dapat diaplikasikan dalam system Akuntansi yang tengah popular saat itu tahun $765 \mathrm{H} / 1363 \mathrm{M}$.

- Akuntansi Bangunan

- Akuntasi Pertanian

- Akuntansi Pergudangan

- Akuntansi Pemuatan Uang

- Akuntasi Pemeliharaan Binatang 
Bahkan di antara yang sangat unik dalam pencatatan pembukuan pada masa tersebut dan juga merupakan pembeda antara Akuntansi yang murni syariah dengan konvensional adalah sebagai berikut;

Sebelum menyiapkan laporan atau dimuat di buku-buku Akuntansi harus dimulai dengan Basmallah. Hal inilah yang juga disebutkn oleh Lucas Pacioli 131 tahun kemudian (Johnson, 1963)

Laporan keuangan dibuat berdasarkan fakta buku Akuntansi yang digunakan, di antara laporan keuangan yang pernah dibuat di Negara Islam yang terkenal adalah $a l$ Khitamah dan al-Khitamatul Jami'ah. al Khitamah merupakan sebuah laporan keuangan tiap akhir bulan dan juga memuat pemasukan serta pengeluaran sesuai kelompok jenisnya sedangkan al-Khitamatul Jami'ah laporan keuangan yang ditujukan untuk orang yang lebih tinggi derajatnya untuk kemudian diberi persetujuan laporan keuangan yang persetujuanya diberi nama al-Muwafaqah namun apabila ia tak disetujui maka ia dinamakan Muhasabah karena adanya perbedaan pada data-data yang dimuat dalam laporan keuangan.

Ketika melakukan transaksi jual beli, tanda terima diberikan kepada pembeli atau disebut juga dengan Thiraz sedangkan copiannya atau salinan disebut sebagai syahid yang kemudian disimpan oleh Akuntan untuk kemudian dipertanggungjawabkan dan disetujui oleh pimpinan kantor, menteri, atau sultan dan apabila transaksi perdagangan terjadi di luar kota salinan syahid tersebut dikirim ke ibukota wilayah Islam untuk kemudian diberikan persetujuan oleh Sultan dan disimpan sebagai dasar pembukuan dasar kantor pusat

Pada akhir tahun buku, seorang akuntan harus mengirimkan laporan keuangan dalam setahun dan secara rinci

Harus mengelompokkan transaksi-transaksi keuangan dan mencatatnya sesuai dengan karakternya dalam kelompok-kelompok yang sejenis.

Dari kenyataan tersebut menunjukkan bahwa peradaban Barat tidak jujur dalam ilmu pengetahuan. Mereka mengakui apa yang mereka pandang berasal dari mereka dan hasil penemuan mereka. Barat tidak mengakui karya umat Islam, namun mereka telah menduplikasi dan menggunakan pemikiran dan karya umat Islam. Oleh karena itu, banyak karya-karya orang Islam yang diterjemah dalam bahasa Barat, namun mereka tidak menyebutkan pengarangnya dan itu diakui sebagai karya mereka.

Sejarah menunjukkan bahwa banyak ilmuwan muslim yang telah berhasil menorehkan karya fenomenal pada teori ekonomi semisal Ibnu Taimiyyah, Ibnu Rushd, Ibnu Khaldun, al Ghazali dan masih banyak lagi. Banyak karya yang dihasilkan oleh para ilmuwan muslim tersebut telah berkontribusi terhadap perkembangan ilmu ekonomi. Namun hal yang menyedihkan justru teori-teori mereka diklaim berasal dari Barat, padahal kalau kita kaji teori ekonomi yang signifikan pada dunia Barat, pertama kali dihasilkan oleh seorang profesor dari University of Glasgow yang bernama Adam Smith pada bukunya "An Inquiry Into The Nature and Cause Of The Wealth of Nations". Buku tersebut dihasilkan pada abad ke-18, yang bahkan isinya banyak terdapat kemiripan dengan buku 'Muqaddimah' karya Ibn Khaldun yang dihasilkan beberapa abad sebelumnya.

Tokoh selanjutnya adalah al-Ghazali yang menyatakan bahwa kebutuhan hidup manusia itu terdiri dari tiga, kebutuhan primer (darruriyyah), sekunder (hajiat), dan 
kebutuhan mewah (takhsiniyyat). Teori hirarki kebutuhan ini kemudian 'diambil' oleh William Nassau Senior yang menyatakan bahwa kebutuhan manusia itu terdiri dari kebutuhan dasar (necessity), sekunder (decency), dan kebutuhan tertier (luxury) (Imaduddin, 2011).

\section{Pengaruh Islam Terhadaap Ilmu Akuntansi}

Tujuan ajaran Islam secara tegas merekomendasikan bahwa transaksi yang dilakukan oleh bisnis harus dicatat dan dibukukan dan terdokumentasikan dengan cara yang benar sesuai dengan fakta agar data keuangan dan informasi keuangan itu baik oleh internal sendiri maupun pihak-pihak eksternal yang relevan terkait dapat dipergunakan dengan akurat berdasarkan prinsip; obyektifitas, keadilan dan kebenaran terutama oleh pihak-pihak yang berkepentingan dalam manajemen amanah dan memenuhi kepentingan informative dari semua pihak yang terkait secara relevan. (Muslich, 2007).

Sebagaimana diketahui bahwa transaksi yang dicatat dan dibukukan dalam akuntansi syariah hanya transaksi yang dibenarkan dalam syariah. Baik dengan segala persyaratanya maupun klausul dibenarkanya transaksi tersebut sesuai dengan prinsipprinsip syariah. (Wiyono, 2005). Transaksi yang secara Syariah ini sebagai suatu ilustrasi yang terjadi pada bisnis Syariah antara lain diklasifikasikan sebagai berikut:

- Transaksi Proyek Murabahah

- Transaksi Bai' Proyek As Salam

- Transaksi Proyek Istisna.

- Transaksi Proyek Mudharabah dan Musyarakah

- Tansaksi Ijaroh.

Pencatatan dan kedudukan dalam akuntansi Islam mencerminkan tindakan yang mendukung prinsip keadilan yang harus dilakukan oleh para pelaku bisnis syariah. Oleh karena itu pencatatan dan pembukuan harus mencerminkan pemaparan yang obyektif sesuai dengan kebenaran data dan informasi yang direkap dalam akuntansi syariah. (Muhammad, 1998). Nilai prinsip dan pertanggung jawaban dalam akuntansi syariah dalam proses pencatatan dan laporannya menganut system berikut:

- Prinsip Pertangungjawaban (Accountabilitas)

- Prinsip Keadilan (Equilibrium)

- Prinsip Kebenaran (Judgement).

Semua pencatatan transaksi keuangan bisnis harus merupakan catatan yang dapat dipertanggung jawabakan kepada semua pihak termasuk kepada Allah sebagai pemberi amanah kepada pelaku bisnis melalui pelaksanaan pencatatan dan pembukuan dalam Akuntansi Syariah. Dan prinsip berikutnya adalah prinsip kebenaran, yaitu semua catatan dan transaksi yang dialami dan lakukan adalah catatan dan transaksi yang benar dan sesuai dengan fakta, apa adanya. Tidak mengenal dalam akuntansi Syariah adanya rekayasa dan tidak mengenal rekayasa window dressing dalam praktik akuntansi:36

Undertand ability, yaitu bahwa laporan keuangan yang dihasilkan oleh akuntansi syariah, memiliki kelebihan yaitu lebih terbuka dan memiliki kemampuan lebih 
transparan, obyektif dan terbuka sehingga mudah difahami dan diketahui oleh pihakpihak yang berkepentingan dan public.

Relevance, yaitu suatu akuntasi yang menekankan pada catatan yang relevan dengan kepentingan siapapun stake holders-nya.

Andal. Hasil yang didapat dari akuntansi syariah cukup diandalkan kevaliditasnya. Karena di dalamnya menekankan pada kejujuran, kebenaran dan obyektivitas secara sesuai dengan mekanisme transaksi dengan penilaian yang sesuai dengan penilaian yang adil dan obyektif.

Comparability. Dapat diperbandingkan dengan kejadian terkait dan dapat diperbandingkan dengan kejadian terkait secara benar dan tak ada manipulasi dan tak ada kejadian tersembunyi.

Audit ability. Memudahkan dalam tugas audit, karena di dalam audit dimungkinkan terjadinya suatu penyimpangan fakta transaksi. Sementara akuntansi syariah mendukung pelaporan keuangan yang jujur, benar dan obyektif dan dapat dipertanggungjawabankan kebenaranya.

\section{KESIMPULAN}

Akuntansi merupakan ilmu yang diderivasi dari nilai-nilai normatif al-Quran dan Hadits dalam bentuk yang lebih konkret dan operasional. Ajaran normatif (iman, ilmu dan amal) dapat dipraktikkan dalam aktifitas transaksi sehari-hari, oleh para pelaku ekonomi syariah. Sejarah akuntansi perlu diluruskan karena telah terjadi manipulasi sejarah yang dilakukan oleh Barat. Umat Islam telah banyak memberikan kontribusi terhadap kemajuan ilmu akuntansi dan perkembangan dunia bisnis

Al-Quran dan Hadits merupakan rujukan utama bagi seluruh keilmuwan Islam. Jauh sebelum manusia mengenal ilmu akuntansi, Islam telah memperkenalkan perhitungan melalui ilustrasi pertanggungjawaban amal manusia di hadapan Allah kelak dihari kiamat. Inilah hakekat dari fungsi akuntansi yang memperhitungkan laba-rugi dalam aktifitas berbisnis. Demikian Allah mengilustrasikan kehidupan dunia sebagai aktifitas bisnis/tijarah. Sebagaimana dijelaskan dalam surat (QS. 35. Fathir: 29) dan (QS. 61. ash-Shaf: 10), dan manusia dalam kehidupan dunia ini sedang mempersiapkan laporan laba-rugi. Hal ini karena laba itu $(+)=$ pahala/debit dan rugi itu $(-)=$ dosa/kredit.

Ini adalah ilustrasi yang disampaikan oleh Allah dalam al-Quran, yang mengingatkan kepada kita semua bahwa dalam kehidupan ini kita harus berbuat yang terbaik dan mencetak prestasi untuk mendapat keuntungan yang lebih besar dalam kehidupan ahirat. Konsep dasar sosio economic mengindikasikan bahwa teori akuntansi tidak terbatas pada transaksi-transaksi ekonomi saja, tetapi mencakup keseluruhan transaksi sosial, yang mencakup aspek sosial, mental dan spiritual. 
Warto

\section{REFERENSI}

(Buku)

Barmawi, Ahmad. 2006. 118 Tokoh Muslim Genius Dunia. Jakarta: Restu Agung

Beekun, Issa Rafik. 1996. Islamic Business Athics/ Etika bisnis Islam. Penejemah: Muhammad. Yogyakarta: Pustaka Pelajar.

Departemen Agama RI. 2002. Pedoman Zakat 9 Seri. Jakarta: Bagian Proyek Peningkatan Zakat dan Wakaf.

Harahap, Sofyan Syafri. 2004. Akuntansi Perbankan Syariah. Jakarta: LPFE Usakti

Imaduddin, Muhammad. 2011. Islamic Banking. Finance. and Management. Inggris: Markfield Institute of Higher Education (MIHE). Markfield. Leicestershire.

Kantakji, Samer. 2004. The Role of Islamic Civilization in Developing Accounting Thought. Beirut: Muassasah ar-Risalah.

Muhammad. 1998. Akuntansi Lembaga Keuangan Syariah. Yogyakarta: Sekolah Tinggi Ilmu Syariah Yogyakarta.

Muslich. 2007. Bisnis Syariah. Yogyakarta: Unit Penerbit \& Percetakan STIM YKPN.

Safira. 2013. Rekonstruksi Kerangka Dasar Konseptual Untuk Akuntansi dan Pelaporan Keuangan Syariah. Jakarta: Uviversitas Mercu Buana.

Sueb, Memed. et.al. 2014. Sejarah dan Perkembangan Teori Akuntansi. Jakarta: Fakultas Ekonomi Universitas Mercu Buana

Triyuwono, Iwan. 2017. Perspektif. Metodologi. Dan Teori Akuntansi Syariah. Jakarta: PT. Raja Grafindo Persada.

Wiyono, Slamet. 2005. Akuntansi Perbankan Syariah. Berdasar PSAK dan PAPSI. Jakarta: PT. Gramedia Widiasarana

(Artikel Jurnal Ilmiah)

Ibrahim, Ahmad Abdulkadir. 2015. Historical Evaluation On Islamic Accountancy. International Journal of Business. Economics and Law. Vol. 7. Issue 1 (Aug.). hlm. 11-18

Mohammed, Nor Farizal, Asy'ari Elmiza Ahmad \& Fadzlina Mohd Fahmi, 2016, Accounting Standards and Islamic Financial Institutions: the Malaysian Experience. Journal of Islamic Banking and Finance. June 2016. Vol. 4. No. 1: 33-38. https://doi.org/10.15640/jibf.v4n1a4

Trokic, Amela. 2015. Islamic Accounting; History. Development and Prospects. EJIF European Journal of Islamic Finance ISSN 2421-2172. No.3. Dec (2015). 1-5.

(Prosiding Seminar/ Konferensi)

Bayou, Mohamed S. M. Salem. 2017. The Nature of Islamic Accounting and Methodology Used in Muslim Countries: Practical Application in UAE. 
Proceedings of the 18th Asian Academic Accounting Association (FourA) Annual Conference. 22-23 November 2017. Bali. Indonesia. hal. 192-199.

Napier, Christopher. 2007. Other Cultures. Other Accountings? Islamic Accounting From Past To Present. 5th Accounting History International Conference. 9-11August 2007. Banff. Canada. hal. 1-34 